\title{
Applications of Calorimetry in the Field of Thermodynamic Properties of the Aqueous Borate Systems
}

\section{Jing LI}

Tianjin Key Lab of Marine Resources \& Chemistry, College of Chemical Engineering and Materials Science, Tianjin University of Science \& Technology, Tianjin, 300457, PRC

\section{Ya-fei GUO}

Tianjin Key Lab of Marine Resources \& Chemistry, College of Chemical Engineering and Materials Science,

Tianjin University of Science \& Technology, Tianjin, 300457, PRC

College of Chemistry \& Materials Science, Northwest University, Xi'an 710127, PRC

\section{Tian-long DENG*}

Tianjin Key Lab of Marine Resources \& Chemistry, College of Chemical Engineering and Materials Science,

Tianjin University of Science \& Technology,

Tianjin, 300457, PRC

e-mail: tldeng@ tust.edu.cn

\begin{abstract}
Owing to the high performance of borate crystals, they are widely used in the fields of mobile communications and other high technology. Researches on thermodynamic properties of aqueous borate systems are essential for the synthesis of borates and the comprehensive utilization of boron-containing brine resources. The calorimeter technique is a new experimental precision method for thermodynamic property measurement. The characteristics of calorimeter technique, standard molar formation enthalpies of alkalis borates and alkalis earth borates, and the thermodynamic properties of aqueous borate systems were summarized in this paper. The key problems in the study of the thermodynamic property of borates and the new trend in the future were also pointed out.
\end{abstract}

Keywords-Borates; Calorimetry; Thermodynamic Property.

\section{INTRODUCTION}

In recent years, borates inorganic functional materials have been widely used in the high technology fields. Boron resources are mainly existed in solid boron minerals in the northeast of Liaoning, Jilin and liquid ores in salt lake brines, especially in Qinghai and Tibet [1]. Researches on thermodynamic properties are of great significance for building chemistry models of electrolyte solution with borate systems, exploiting and comprehensive utilization of boroncontaining brine resources [2]. Methods of measuring electrolyte solution thermodynamics properties mainly include isobaric method, E.M.F method and calorimetry, etc.

\section{Long LI}

Tianjin Key Lab of Marine Resources \& Chemistry, College of Chemical Engineering and Materials Science, Tianjin University of Science \& Technology, Tianjin, 300457, PRC

\section{Si-si ZHANG}

Tianjin Key Lab of Marine Resources \& Chemistry, College of Chemical Engineering and Materials Science, Tianjin University of Science \& Technology, Tianjin, 300457, PRC

The change of material energy can be determined more directly, rapidly and accurately by calorimetry, compared with isobaric method and E.M.F method. The calorimetry is widely used in the research of borates, especially borates solution chemistry and thermo chemical properties [3]. In this paper, characteristics of calorimeter technique and thermodynamic properties of borates and aqueous borate systems were summarized.

\section{THE CHARACTERISTICS OF CALORIMETER TECHNIQUE}

Calorimeter techniques mainly include differential scanning calorimetry (DSC), adiabatic calorimetry and titration calorimetry, etc. DSC is the most widely used thermal analysis technique to measure the temperatures and heat flows associated with transition in materials as a function of time and temperature. Such measurements mainly provide the information about physical and chemical changes that involve endothermic or exothermic processes, or changes in heat capacities [4]. Calvar et al. [5] determined the thermal behavior and heat capacities of pyridinium and two imidazolium-based ionic liquids from 133.15 to 395.15 $\mathrm{K}$ by using DSC. In recent years, the heats of solution and heat capacities of trace liquid samples also were measured with DSC. Such as Archer et al. [6] determined the heat capacities of $\mathrm{NaCl}+\mathrm{H}_{2} \mathrm{O}$ system from $205.15 \mathrm{~K}$ to $293.15 \mathrm{~K}$, at $0.1 \mathrm{MPa}$ by using DSC, and explained the anomalous reason of thermodynamic properties at $273.15 \mathrm{~K}$. 
DSC/DTA thermal analysis technique is easy to cause experimental error owing to the small volume of sample crucibles (about $10 \mathrm{mg}$ ), especially for liquid samples with a poor uncertainty $\pm 5 \%$. Compared with the DSC, the adiabatic calorimeter equipped with a larger cell in the internal volume can reduce the error caused by less sampling, such as adiabatic microcalorimeter (BT2.15, Setaram, France) equipped with the standard sample pond maximum volume of approximately $12.5 \mathrm{~cm}^{3}$ in our laboratory. The microcalorimeter has a 3D sensors with an uncertainty within $\pm 0.001 \mathrm{~K}$ and the heating rate can be controlled in $0.01 \sim 2 \mathrm{~K} \cdot \mathrm{min}^{-1}$. Adiabatic calorimeter has been widely applied to measure the heat capacities of substances and thus obtain important information in many aspects such as structures and phase transitions [7]. Adiabatic calorimeter can be divided into high-temperature and low-temperature, and the low-temperature is a difficult point in the microcalorimeter analysis technique.

Titration calorimetry is a technique where one reactant is titrated into another and the temperature of the system is measured as a function of added titrant. Isothermal titration calorimetry (ITC) can measure directly the energy associated with a chemical reaction triggered by the mixing of two components, and the instrument is so sensitivity that can detect a micro heat change less than $100 \mathrm{~nJ}$ produced by 1 nmol biological samples. ITC has been widely applied in the research frontier of nano soft materials science, polymer or surfactant interactions, etc [8].

\section{THE THERMODYNAMIC PROPERTIES OF BORATE SYSTEMS}

\section{A. The Standard Molar Enthalpies of Formation of Alkalis Borates}

In the past few decades, the calorimetry researches for alkalis borates of have been widely researched. Zhu et al. [9], $\mathrm{Li}$ and Zhu [10-13], Li et al. [14-15] determined the standard molar enthalpy of formation of $\mathrm{LiBO}_{2} \cdot 2 \mathrm{H}_{2} \mathrm{O}$, and $\mathrm{LiBO}_{2} \cdot 8 \mathrm{H}_{2} \mathrm{O}$, etc by using the microcalorimeter. Zhu et al. [16] determined the standard molar enthalpies of formation of $\mathrm{KB}_{5} \mathrm{O}_{8} \cdot 4 \mathrm{H}_{2} \mathrm{O}$ and $\mathrm{RbB}_{5} \mathrm{O}_{8} \cdot 4 \mathrm{H}_{2} \mathrm{O}$, etc by using an RD496III microcalorimeter. All of the standard molar entropies of formation of alkalis borates were determined by calorimetry. The standard molar entropies of formation of alkalis borates were given in Table 1.

\section{B. The Standard Molar Enthalpies of Formation of Alkalis Earth Borates}

Similar as alkalis borates, the standard molar formation enthalpies of alkalis earth borates also have been reported. Liu et al. [18-19], Li et al. [20-23], Gurevich et al. [24], Li et al. [25] determined the standard molar formation enthalpies of $\mathrm{MgB}_{2} \mathrm{O}_{4} \cdot 3 \mathrm{H}_{2} \mathrm{O}$ and $\mathrm{Ca} 2 \mathrm{~B}_{6} \mathrm{O}_{11} \cdot 5 \mathrm{H}_{2} \mathrm{O}$, etc by using a calorimetric. Moreover, Liu et al. [26-27], Zuo [28] got the standard molar formation enthalpies of $\mathrm{Ca}_{2} \mathrm{~B}_{2} \mathrm{O}_{5} \cdot \mathrm{H}_{2} \mathrm{O}$ and $\mathrm{SrB}_{6} \mathrm{O}_{10} \cdot 5 \mathrm{H}_{2} \mathrm{O}$, etc by using a calorimeter. The standard molar formation entropies of alkalis earth borates were given in Table 1.

TABLE I. STANDARD MOLAR FORMATION ENTHALPIES OF ALKALIS BORATES AND ALKALIS EARTH BORATES BY CALORIMETRY.

\begin{tabular}{|c|c|c|c|c|c|}
\hline Alkalis borates & $\Delta_{f} H_{m}{ }^{\theta} /\left(\mathrm{kJ} \cdot \mathrm{mol}^{-1}\right)$ & Ref. & Alkalis earth borates & $\begin{array}{c}\Delta_{f} H_{m}{ }^{\theta} / \\
\left(\mathrm{kJ} \cdot \mathrm{mol}^{-1}\right) \\
\end{array}$ & Ref. \\
\hline $\mathrm{Li}\left[\mathrm{B}(\mathrm{OH})_{4}\right]$ & -1627.5 & [9] & $\mathrm{Mg}\left[\mathrm{B}_{2} \mathrm{O}(\mathrm{OH})_{6}\right]$ & -2842.7 & {$[22]$} \\
\hline $\mathrm{Li}\left[\mathrm{B}(\mathrm{OH})_{4}\right] \cdot 6 \mathrm{H}_{2} \mathrm{O}$ & -3397.0 & [9] & $\mathrm{MgB}_{4} \mathrm{O}_{5}(\mathrm{OH})_{4} \cdot 7 \mathrm{H}_{2} \mathrm{O}$ & -5807.1 & [20] \\
\hline$\left[\mathrm{LiB}_{2} \mathrm{O}_{3}(\mathrm{OH})\right]_{2} \cdot 2 \mathrm{H}_{2} \mathrm{O}$ & -4290.9 & {$[14]$} & $\mathrm{MgB}_{6} \mathrm{O}_{7}(\mathrm{OH})_{6} \cdot 2 \mathrm{H}_{2} \mathrm{O}$ & -6063.7 & [29] \\
\hline $\mathrm{Li}\left[\mathrm{B}_{5} \mathrm{O}_{6}(\mathrm{OH})_{4}\right] \cdot 3 \mathrm{H}_{2} \mathrm{O}$ & -5130.3 & {$[14]$} & $\mathrm{MgB}_{6} \mathrm{O}_{7}(\mathrm{OH})_{6} \cdot 3 \mathrm{H}_{2} \mathrm{O}$ & -6294.7 & {$[22]$} \\
\hline $\mathrm{Li}_{3} \mathrm{~B}_{5} \mathrm{O}_{8}(\mathrm{OH})_{2}(\mathrm{I})$ & -4724.1 & {$[10]$} & $\mathrm{MgB}_{6} \mathrm{O}_{7}(\mathrm{OH})_{6} \cdot 4 \mathrm{H}_{2} \mathrm{O}$ & -6588.8 & {$[22]$} \\
\hline $\mathrm{Li}_{3} \mathrm{~B}_{5} \mathrm{O}_{8}(\mathrm{OH})_{2}(\mathrm{II})$ & -4723.8 & {$[10]$} & $\mathrm{MgB}_{6} \mathrm{O}_{7}(\mathrm{OH})_{6} \cdot 4.5 \mathrm{H}_{2} \mathrm{O}$ & -6735.3 & [22] \\
\hline $\mathrm{Li}_{8}\left[\mathrm{~B}_{16} \mathrm{O}_{26}(\mathrm{OH})_{4}\right] \cdot 6 \mathrm{H}_{2} \mathrm{O}$ & -15943.0 & {$[13]$} & $\mathrm{MgB}_{3} \mathrm{O}_{3}(\mathrm{OH})_{5} \cdot 5 \mathrm{H}_{2} \mathrm{O}$ & -9626.5 & [22] \\
\hline $\mathrm{Na}\left[\mathrm{B}(\mathrm{OH})_{4}\right]$ & -1581.5 & {$[17]$} & $\mathrm{MgB}_{3} \mathrm{O}_{3}(\mathrm{OH})_{5} \cdot 5 \mathrm{H}_{2} \mathrm{O}$ & -9631.9 & {$[22]$} \\
\hline $\mathrm{Na}\left[\mathrm{B}(\mathrm{OH})_{4}\right] \cdot 2 \mathrm{H}_{2} \mathrm{O}$ & -2175.7 & {$[17]$} & $\mathrm{MgB}_{3} \mathrm{O}_{3}(\mathrm{OH})_{5} \cdot 6 \mathrm{H}_{2} \mathrm{O}$ & -20512.8 & [19] \\
\hline $\mathrm{Na}_{2}\left[\mathrm{~B}_{4} \mathrm{O}_{6}(\mathrm{OH})_{2}\right] \cdot 3 \mathrm{H}_{2} \mathrm{O}$ & -4507.4 & {$[17]$} & $\mathrm{MgB}_{3} \mathrm{O}_{3}(\mathrm{OH})_{5} \cdot 6 \mathrm{H}_{2} \mathrm{O}$ & -10272.1 & {$[22]$} \\
\hline $\mathrm{Na}_{2}\left[\mathrm{~B}_{4} \mathrm{O}_{5}(\mathrm{OH})_{4}\right] \cdot 3 \mathrm{H}_{2} \mathrm{O}$ & -4802.4 & {$[17]$} & $\mathrm{Mg}\left[\mathrm{B}_{6} \mathrm{O}_{9}(\mathrm{OH})_{2}\right] \cdot 2.5 \mathrm{H}_{2} \mathrm{O}$ & -11190.0 & [19] \\
\hline $\mathrm{Na}_{2}\left[\mathrm{~B}_{4} \mathrm{O}_{5}(\mathrm{OH})_{4}\right] \cdot 8 \mathrm{H}_{2} \mathrm{O}$ & -6288.5 & {$[17]$} & $\mathrm{Ca}\left[\mathrm{B}(\mathrm{OH})_{4}\right]_{2}$ & -3228.1 & [25] \\
\hline $\mathrm{Na}\left[\mathrm{B}_{5} \mathrm{O}_{6}(\mathrm{OH})_{4}\right] \cdot 3 \mathrm{H}_{2} \mathrm{O}$ & -5099.8 & {$[15]$} & $\mathrm{Ca}\left[\mathrm{B}(\mathrm{OH})_{4}\right]_{2} \cdot 2 \mathrm{H}_{2} \mathrm{O}$ & -3811.1 & {$[25]$} \\
\hline$\alpha-\mathrm{Na}_{2} \mathrm{~B}_{5} \mathrm{O}_{8}(\mathrm{OH}) \cdot 2 \mathrm{H}_{2} \mathrm{O}$ & -9450.2 & {$[11]$} & $\mathrm{Ca}\left[\mathrm{B}_{6} \mathrm{O}_{9}(\mathrm{OH})_{2}\right] \cdot 3 \mathrm{H}_{2} \mathrm{O}$ & -5819.1 & {$[25]$} \\
\hline$\beta-\mathrm{Na}_{2} \mathrm{~B}_{5} \mathrm{O}_{8}(\mathrm{OH}) \cdot 2 \mathrm{H}_{2} \mathrm{O}$ & -9438.0 & {$[11]$} & $\mathrm{Ca}\left\{\mathrm{B}_{5} \mathrm{O}_{8}(\mathrm{OH}) \cdot \mathrm{B}(\mathrm{OH})_{3}\right\} \cdot 3 \mathrm{H}_{2} \mathrm{C}$ & -6096.4 & {$[25]$} \\
\hline $\mathrm{Na}_{6}\left[\mathrm{~B}_{4} \mathrm{O}_{5}(\mathrm{OH})_{4}\right]_{3} \cdot 8 \mathrm{H}_{2} \mathrm{O}$ & -14093.0 & {$[12]$} & $\mathrm{Ca}_{2}\left[\mathrm{~B}_{2} \mathrm{O}_{4}(\mathrm{OH})_{2}\right]$ & -3041.8 & [26] \\
\hline $\mathrm{KB}_{5} \mathrm{O}_{6}(\mathrm{OH})_{4} \cdot 2 \mathrm{H}_{2} \mathrm{O}$ & -4834.2 & {$[15]$} & $\mathrm{Ca}_{2}\left[\mathrm{~B}_{2} \mathrm{O}_{4}(\mathrm{OH})_{2}\right] \cdot 0.5 \mathrm{H}_{2} \mathrm{O}$ & -3172.5 & [28] \\
\hline $\mathrm{K}_{3}\left[\mathrm{~B}_{3} \mathrm{O}_{4}(\mathrm{OH})_{4}\right] \cdot 2 \mathrm{H}_{2} \mathrm{O}$ & -1411.1 & {$[17]$} & $\mathrm{Ca}\left[\mathrm{B}_{3} \mathrm{O}_{5}(\mathrm{OH})\right]$ & -5733.7 & {$[28]$} \\
\hline $\mathrm{K}_{2} \mathrm{~B}_{4} \mathrm{O}_{5}(\mathrm{OH})_{4} \cdot 2 \mathrm{H}_{2} \mathrm{O}$ & -4568.8 & {$[15]$} & $\mathrm{Ca}\left[\mathrm{B}_{3} \mathrm{O}_{4}(\mathrm{OH})_{3}\right] \cdot \mathrm{H}_{2} \mathrm{O}$ & -6939.6 & {$[24]$} \\
\hline $\mathrm{K}_{4}\left[\mathrm{~B}_{10} \mathrm{O}_{15}(\mathrm{OH})_{4}\right]$ & -8651.0 & {$[12]$} & $\mathrm{Ca}\left[\mathrm{B}_{3} \mathrm{O}_{3}(\mathrm{OH})_{5}\right] \cdot 2 \mathrm{H}_{2} \mathrm{O}$ & -8056.3 & {$[25]$} \\
\hline $\mathrm{K}\left[\mathrm{B}_{5} \mathrm{O}_{6}(\mathrm{OH})_{4}\right] \cdot 2 \mathrm{H}_{2} \mathrm{O}$ & -4834.2 & {$[15]$} & $\mathrm{Ca}\left[\mathrm{B}_{3} \mathrm{O}_{3}(\mathrm{OH})_{5}\right] \cdot 4 \mathrm{H}_{2} \mathrm{O}$ & -9294.3 & {$[24]$} \\
\hline $\mathrm{Rb}\left[\mathrm{B}_{5} \mathrm{O}_{6}(\mathrm{OH})_{4}\right] \cdot 2 \mathrm{H}_{2} \mathrm{O}$ & -4837.3 & {$[16]$} & $\mathrm{Ca}_{4}\left[\mathrm{~B}_{5} \mathrm{O}_{7}(\mathrm{OH})_{5}\right]_{2} \cdot 2 \mathrm{H}_{2} \mathrm{O}$ & -11658.7 & [28] \\
\hline $\mathrm{Cs}_{2} \mathrm{~B}_{7} \mathrm{O}_{9}(\mathrm{OH})_{5}$ & -6099.0 & [13] & $\mathrm{Ca}_{4}\left[\mathrm{~B}_{5} \mathrm{O}_{7}(\mathrm{OH})_{5}\right]_{2} \cdot 2 \mathrm{H}_{2} \mathrm{O}$ & -11578.7 & [28] \\
\hline
\end{tabular}


It should be pointed out that majority of alkalis and alkalis earth borates, which showed in Table 1, were synthetized in laboratory. Up to now, the sixteen kinds of natural alkalis and alkalis earth borates minerals have been contained in the Tables 1, but natural alkalis and alkalis earth borates complex salt minerals, such as natroborocalcite $\left(\mathrm{NaCaB}_{5} \mathrm{O}_{9} \cdot 8 \mathrm{H}_{2} \mathrm{O}\right)$, hydroboracite $\left(\mathrm{MgCaB}_{6} \mathrm{O}_{11} \cdot 6 \mathrm{H}_{2} \mathrm{O}\right)$, and other minerals have not been reported yet.

\section{The Thermodynamic Properties of Aqueous Borate Systems}

In the past decades, the application of calorimetry for the thermodynamic properties including heat capacities, dissolution heats and heats of dilution of borate systems has attracted great attention. Yin et al. [30] had achieved the enthalpies of dilution and the relative apparent molar enthalpies of aqueous $\mathrm{Li}_{2} \mathrm{~B}_{4} \mathrm{O}_{7}$ solutions from 0.0212 to $2.1530 \mathrm{~mol} \cdot \mathrm{kg}^{-1}$ at $298.15 \mathrm{~K}$ and further represented the thermodynamic properties of the complex aqueous solutions with a modified Pitzer ion-interaction model. Again, Zhang et al. [31-32] determined the molar heat capacities of aqueous $\mathrm{Li}_{2} \mathrm{~B}_{4} \mathrm{O}_{7}$ solution at $0.3492 \mathrm{~mol} \cdot \mathrm{kg}^{-1}$ and 0.0187 mol.kg-1 with a precision automated adiabatic calorimeter at the temperature range from 80 to $356 \mathrm{~K}$ and 80 to $355 \mathrm{~K}$, respectively. At the same time, the temperatures of the phase transition of aqueous $\mathrm{Li}_{2} \mathrm{~B}_{4} \mathrm{O}_{7}$ solution at 0.3492 and 0.0187 $\mathrm{mol} \cdot \mathrm{kg}^{-1}$ were observed at 271.72 and $273.04 \mathrm{~K}$ on the basis of the curve of the heat capacity with temperature.

The studies on thermodynamic properties of multicomponent systems including borates have been reported. Yin et al. [33] obtained the enthalpies of dilution and the relative apparent molar enthalpies for ternary systems $\left(\mathrm{Li}_{2} \mathrm{~B}_{4} \mathrm{O}_{7}+\mathrm{LiCl}+\mathrm{H}_{2} \mathrm{O}\right)$ at three different molar fractions of $\mathrm{Li}_{2} \mathrm{~B}_{4} \mathrm{O}_{7}$ at $298.15 \mathrm{~K}$ by using a microcalorimeter to derive the relationships relative apparent molar enthalpy and ionic strength. In addition, Li et al. [34-36] obtained the heats of dilution, heat capacities and relative apparent molar enthalpies of the system of $\mathrm{MgO} \cdot \mathrm{nB}_{2} \mathrm{O}_{3} \cdot \mathrm{MgC}_{12} \cdot \mathrm{H}_{2} \mathrm{O}(\mathrm{n}=1,2$, 3 ) at $298.15 \mathrm{~K}$ with the continuous dilution method by using the LK8700-1 precision calorimeter, and the data of the heat of dilution were extrapolated to infinite dilution by use of Debye-Huckel limiting law to obtain relative apparent molar enthalpies over a range of ionic strengths. Using the same method, the heats of dilution and heat capacities of the quaternary systems of $\left(\mathrm{Li}_{2} \mathrm{~B}_{4} \mathrm{O}_{7}+\mathrm{Li}_{2} \mathrm{SO}_{4}+\mathrm{LiCl}+\mathrm{H}_{2} \mathrm{O}\right)$, $\left(\mathrm{MgB}_{4} \mathrm{O}_{7}+\mathrm{MgSO}_{4}+\mathrm{H}_{2} \mathrm{O}\right)$ and their subsystems were measured at $298.15 \mathrm{~K}$. The result make clear that the ionic strength $\mathrm{I}$ is higher or the molalities are greater, the heat capacities are smaller and the apparent molar enthalpies are greater in the aqueous solution system containing high concentrations of magnesium, lithium and borate ions. Above all, the result provides a theoretical foundation for the research of heats of dilution for multicomponent systems.

Throughout the study of thermodynamic properties of borates aqueous solution system by calorimetry, we can find that most parameters of thermodynamic properties were achieved with the calorimeter technique. The relative apparent molar enthalpies can be obtained by using DebyeHuckel limiting law and together with the relationships between the apparent molar enthalpies and molalities. However, the thermodynamic properties of borates aqueous solutions represented with a modified Pitzer ion-interaction model are yet to be further theoretical innovation.

\section{The Thermodynamic Properties of the Other Borates}

Gao et al. [37], Wang et al. [38] successfully synthesized hydrated zinc borates including $4 \mathrm{ZnO} \cdot \mathrm{B}_{2} \mathrm{O}_{3} \cdot \mathrm{H}_{2} \mathrm{O}$, $3 \mathrm{ZnO} \cdot 3 \mathrm{~B}_{2} \mathrm{O}_{3} \cdot 3.5 \mathrm{H}_{2} \mathrm{O}$ and $6 \mathrm{ZnO} \cdot 5 \mathrm{~B}_{2} \mathrm{O}_{3} \cdot 3 \mathrm{H}_{2} \mathrm{O}$ in the laboratory. All the standard molar enthalpies of formation of artificial synthesis borates were determined by using an RD496-III heat conduction microcalorimeter, which will not repeat here.

\section{CONCLUSION}

Based on the rich resources containing borate and characteristics of calorimetric technique, thermodynamic properties of alkalis and alkalis earth borates and borates aqueous solution system were summarized in this paper. Up to now, thermodynamic properties of borates aqueous solution system mostly concentrated in the normal temperature and pressure, and a narrow temperature range. It is worthy of saying that the research on the thermodynamic properties of borates using calorimetry and Pitzer ioninteraction model are scarce, so there are a lot of work remains to be further explored.

\section{ACKNOWLEDGMENT}

This work is supported by the Laboratory Foundation of Chinese Universities (SY2015018) and the Chinese Postdoctoral Science Foundation (2016M592827).

Work partially supported by the National Natural Science Foundation of China (21276194, 21306136 and U1407113).

\section{REFERENCES}

[1] W. Zhao, Y.F. Guo and J. Gao, et al, World Sci-tech R\&D 33, 29 (2011).

[2] A.R. Felmy and J.H. Weare, Geochim. Cosmochim. Acta 502771 (1986).

[3] T.L. Deng, H. Zhou and X. Chen, Salt-Water System Phase Diagrams and Applications (Beijing: Chemical Industry Press, 2013)

[4] P. Gill, S. Sauerbrunn and M. Reading, J. Therm. Anal. Calorim. 40 931 (1993).

[5] N. Calvar, E. Gómez, and E.A. Macedo, et al, Thermochim. Acta 565 178 (2013).

[6] D.G. Archer and R.W. Carter, J. Phys. Chem. B 1048563 (2000).

[7] Z.C. Tan and Y.Y. Di, Prog. Chem. 181234 (2006).

[8] N. Karim and S. Kidokoro, Thermochim. Acta 41291 (2004).

[9] L.X. Zhu, S.Y. Gao and S.P. Xia, Thermochim. Acta 419105 (2004).

[10] P. Li and Z.H. Liu, J. Chem. Eng. Data 521811 (2007).

[11] P. Li and Z.H. Liu, J. Chem. Eng. Data 56102 (2010).

[12] P. Li and Z.H. Liu, J. Chem. Eng. Data 54830 (2009).

[13] J. Li, B. Li and S.Y. Gao, J. Chem. Thermodyn. 30681 (1998).

[14] J. Li, B. Li and S.Y. Gao, J. Chem. Thermodyn. 30425 (1998).

[15] L.X. Zhu, T. Yue and S.Y. Gao, et al, J. Chem. Thermodyn. 35433 (2003).

[16] D.D. Wagman, W.H. Evans, and V.B. Parke, et al, J. Phys. Chem. Ref. Data 111 (1982).

[17] Z.H. Liu and M.C. Hu, Thermochim. Acta 414215 (2004). 
[18] Z.H. Liu and M.C. Hu, Thermochim. Acta 403181 (2003).

[19] J. Li, S.Y. Gao and Qu J N, et al, J. Appl. Chem. 1012 (1993).

[20] J. Li, P.S. Song and B. Sun, Thermochim. Acta 233211 (1994).

[21] J. Li, S.Y. Gao and S.P. Xia, et al, J. Chem. Thermodyn. 29491 (1997).

[22] J. Li, B. Li and S.Y. Gao, Phys. Chem. Miner. 27342 (2000).

[23] V.M. Gurevich and V.A. Sokolov, Geokhimiya, 3455 (1976).

[24] J. Li, S.Y. Gao, and S.P. Xia, et al, J. Chem. Thermodyn. 291071 (1997).

[25] Z.H. Liu, C.F. Zuo and S.Y. Li, Thermochim. Acta 42459 (2004).

[26] Z.H. Liu, C.F. Zuo and M.C. Hu, Thermochim. Acta 435168 (2005).

[27] C.F. Zuo, Synthesis and Thermochemistry of the Hydrated Calcium Borates

[28] (Xi'an: Shaanxi Normal University, 2005)

[29] Y.Z. Jia, J. Li and Gao S Y, et al, J. Chem. Thermodyn. 311605 (1999).
[30] G.Y. Yin, Y. Yao and B. Jiao, et al, Thermochim. Acta 435125 (2005).

[31] Z.H. Zhang, G.Y. Yin and Z.C. Tan, et al, J. Solution Chem. 351347 (2006).

[32] Z.H. Zhang, Z.C. Tan and G.Y .Yin, et al, J. Chem. Eng. Data 52866 (2007).

[33] G.Y. Yin, Y. Yao and Z.H. Liu, J. Therm. Anal. Calorim. 95377 (2009).

[34] J.C. Li, Z.X. Zhai and Z.M. Zeng, et al, Chin. Sci. Bull. 39249 (1994).

[35] J.C. Li, J.H. Wei and S.Y. Gao, Therm. Anal. Calorim. 52497 (1998).

[36] J.C. Li, L.Y. Wang and Z.M. Zeng, Chin. J. Inorg. Chem. 11409 (1995).

[37] Y.H. Gao and Z.H. Liu, J. Chem. Eng. Data 542789 (2009).

[38] J. Wang, A.Q. Zhang and Z.H. Liu, J. Chem. Thermodyn. 8288 (2015). 